\title{
ENGLISH BORROWINGS AND SCALE OF BORROWABILITY IN VIETNAMESE MAGAZINES
}

\author{
Nguyen Thuy Nga* \\ Hanoi National University of Education, 136 Xuan Thuy, Cau Giay, Hanoi, Vietnam
}

Received 09 March 2017

Revised 09 May 2017; Accepted 12 May 2017

\begin{abstract}
When two or more languages are in contact, it is impossible for them to remain completely discrete from each other and the most frequently encountered product of language contact is lexical borrowing. This paper reviews the background of lexical borrowing in Vietnamese context and investigates the scale of borrowability of English tokens that occured in magazine issues. The findings show that the syntactic system of the Vietnamese language has influenced how English word types are borrowed.
\end{abstract}

Keywords: language contact, borrowings, English, scale of borrowability

\section{Introduction}

Since 1986, the use of English has undergone rapid expansion in Vietnam. Not only are young people exposed to English because it is a subject offered at schools, but they may also gravitate towards it as a prominent tool to enable access to Western lifestyle and culture. Despite substantial studies on English borrowings, no research is conducted on written borrowings, written code-switching, and trends in borrowing over time in language for a youthful Vietnamese audience such as that encountered in magazines for teenagers. The current study innovates in all of these ways. First, consideration of written borrowings is useful in that it allows access to much larger data collections, thereby facilitating meaningful quantitative results. Second, the study of youth language helps capture borrowings closer to their time of entry into the language, since young people, especially in the Englishfocused educational context noted above, can be expected to instigate borrowing more often than older people. Moreover, borrowings examined

* Tel.: 84- 964757807

Email: thuynga.nguyen11@gmail.com over time provide insight into the relation between the influence of English in Vietnamese and the historical, cultural, and educational context in which the effect of English grew, changed, or diminished.

This study analyses the prevalence of English borrowings in Hoa Hoc Tro, a Vietnamese magazine for teenagers, to find out the scale of borrowability of English word types in Vietnamese.

\section{Theoretical Background}

\subsection{Language Contact}

Language contact takes place everywhere. It is hard to find an existing language that survives without having any contact with others. Besides being the main factor leading to the actions of borrowing and code-switching linguistic items, language contact is viewed as one of the external factors that 'can, and often does, lead directly to structural linguistic change' Thomason (2006: 1). Language contact occurs when there is interaction between people from different language backgrounds. Robins (1989: 14) sees language as 'adaptable and modifiable 
according to the changing needs and conditions of speakers'. The adaptability and modifiability of language can be seen in the adaptation of vocabulary to the scientific and industrial developments as well as in the importation of foreign words. Other researchers raise the questions such as to what degree of difference the code used in two 'languages' has to be and whether different dialects are categorised as different languages (Appel \& Muysken, 1987: 3; Thomason, 2001: 3). Thomason (2001: 1) gives a more flexible definition of language contact as 'the use of more than one language in the same place at the same time'. This indicates that fluent bilingualism is not essential but communication between different languages is necessary. Moreover, contact can occur without speakers of two or more languages being in the same place at the same time, as in the case of contact through music, films, internet, books, magazines, and newspapers. Thomason's definition covers a wider range of language contact, including spoken and written contact, and can therefore be used as the guiding definition in this study for the analysis of language contact in Vietnamese magazine.

\subsection{Borrowing}

Borrowing is a natural consequence of language contact. The contact can be either tangible (conquest, boundary contact, and so on) or intangible (high technology, cultural contact, and so forth). Different definitions have existed due to different points of view on borrowing.

Borrowing in Haugen's words is 'the attempted reproduction in one language of patterns previously found in another' (Haugen, 1950: 212). The word 'reproduction' implies the imitation process of speakers of the recipient language. Haugen (1992: 197) later modifies the definition of borrowing as 'the adoption into language of a linguistic feature previously used in another' which focuses on the incorporation or insertion of a foreign element into a language. Based on definitions proposed by previous researchers, Bussmann (1996: 55) describes borrowings as the 'adoption of a linguistic expression from one language into another language, usually when no term exists for the new object, concept or state of affair'. In fact, borrowing includes both imitation (reproduction) and insertion (adoption) because speakers of a native language can nativise the foreign word or simply use it more or less as it is in the donor language.

In Vietnamese, there are three terms that co-exist to refer to borrowing: tù murọn 'borrowed word', tù vay mượn 'loan/ borrowing', and tù ngoại lai 'imported word from outside' Nguyen (2007: 28). Although named differently, they are all used to refer to words borrowed from another language. In English, the words are described as borrowings or loan words, although 'it is more like a kind of stealing' (Haugen, 1956) or "copied rather than borrowed in the strict sense of the word' (Aitchison, 2000) because the 'borrowed' words are never 'returned' to the donor language. Several alternative terms are proposed, such as 'copying' by Johanson (2002), or 'transfer' and 'transference' by Clyne (2003), to replace the well-established word 'borrowing'. Despite being slightly misleading, the word 'borrowing' has been used for a long time, the metaphor is wellestablished and is claimed that it does 'not lead to any misunderstanding' (Haspelmath \& Tadmor, 2009: 37), so this study uses the term 'borrowing' instead of the other terms proposed above.

\subsection{Scale of Borrowability}

In the late nineteenth century, William Dwight Whitney (1881: 19-20) set up a scale based on the comparative ease or difficulty with which patterns are borrowed. In that scale, nouns are most easily borrowed, followed by adjectives, verbs, and other parts 
of speech (adverbs, pronouns, and more), then prefixes and suffixes, and inflections.

(1) nouns $>$ adjectives $>$ verbs $>$ other parts of speech

Since then, other observations have been made on linguistic patterns to determine which part of speech is more or less likely to be borrowed and various types of scales of borrowability have been proposed. A similar scale to Whitney's is elaborated by Haugen (1950: 224), based on the list of American English borrowings in Norwegian and Swedish:

(2) nouns $>$ verbs $>$ adjectives $>$ adverbs, prepositions $>$ interjections

In the study of Spanish borrowings in Ecuadorian Quechua, Van Hout \& Muysken (1994: 42) list the number of types borrowed is in the order:

(3) nouns $>$ verbs $>$ adjectives $>$ sentence adverbs $>$ quantifiers $>$ conjunctions $>$ prepositions $>$ interjections $>$ negation $>$ manner adverbs $>$ greetings

Based on the number of word classes and word formation of English borrowings in German, Onysko (2007: 131) comes up with another order:

(4) nouns $>$ adjectives $>$ verbs $>$ adverbs $>$ others

Field(2002:35)notes that there is correlation between the degree of grammaticalisation and the degree of borrowability. He claims that 'the more structural (or grammaticalised) an element is, the less likely it will be borrowed from one language to another'. Such scales support Field's statement that nouns are the most often borrowed items and the content items are borrowed more frequently than the grammatical ones. The difference in position of the second grammatical category that follows nouns is specific to certain structural properties of the languages. For example, Cree and other Algonquian languages do not have adjectives. As a result, verbs or relative clauses are used to attribute nouns, which leads to an increase of other lexical items rather than adjectives. The position of adjectives or verbs in the scale of borrowability may be the reflection of the distribution of grammatical categories in the recipient language rather than the inclination of such items to be borrowed. Accordingly, Field proposes a scale in which nouns stand at the first place, followed by adjectives and verbs:

(5) nouns $>$ adjectives, verbs

All of the scales proposed concur that nouns are the most frequently borrowed items. The second most borrowed can be either adjectives or verbs, depending on the structure of each language as well as the need for such items. The particular scales in different languages and the general scale affirm that the grammatical apparatus is least likely to be borrowed.

\section{Methodology}

\subsection{The Hoa Hoc Tro magazine}

Hoa Hoc Tro, a weekly off-shoot of the Vietnamese Student newspaper, was first published on 15 October 1991. Hoa Hoc Tro includes information, articles and stories for the younger generation. Being the first magazine for high school students in Vietnam, after a few years since its foundation in 1991, Hoa Hoc Tro reached a circulation of 100,000 per week, becoming one of the top circulating periodicals in Vietnam and currently sells 200,000 copies weekly Duong (2011). Hoa Hoc Tro provides opportunities for students to have their own magazine to which they can contribute by writing and expressing their ideas, and as a result, new word usages have been presented and developed. Many of the stories, poems, and so on in the magazines are written by student writers (e.g., at high schools, colleges, and universities). Hoa Hoc Tro, then, is one of the favourite magazines among Vietnamese teenagers and a good source of data on teen language use. 


\subsection{Data collection and analysis}

This research collects English words in 111 Hoa Hoc Tro magazine issues starting from the first issue in 1991 using stratified sampling method, that is, one issue of each month is collected for the study. The borrowings appearing in each issue of the magazine are identified and classified into different word classes according to their usages. Proper names, title of songs, movies, books, translations of letters to idols, abbreviation of international units of measurement, and quotations are excluded from this study.

English words that meet one of the following criteria are subjects of the study:

1. An English word used in Vietnamese whose origin can be traced back to English is counted each time it appears in the magazine.

2. An acronym of an English phrase acting as a word in Vietnamese is counted as one word, for example: $U F O$ (unidentified flying object), and $C D$ (compact disk).

3. Noun Phrases such as crazy fan, sky train, smash hits, fan club, video clip, and stock exchange are counted as one entry.

4. Inflected forms of the same lexeme are counted as one word. For example fan and fans are counted as the same word.

5. Duplicated words such as bye bye are counted as one word.
6. Phrases and clauses such as Happy New Year to you and Oh, fashion is always crazy are selected and listed in a separate list for code-switching, hence, they are not added to the number of borrowings analysed.

\section{Finding}

Table 1 illustrates the type frequency of borrowings, showing the probability for words of a particular type to be borrowed; and the token frequency, which sheds light on the frequency of each type and thus addresses the likelihood that borrowings in each word type will catch on. As can be seen from Table 1, in terms of token frequency, of the 830 types of the 5138 tokens English borrowings imported into Hoa Hoc Tro, nouns constitute the largest group at $88.1 \%$, verbs account for $4.2 \%$, adjectives make up 3.5\%, and adverbs and prefixes occupy $0.3 \%$ each. Prepositions, quantifiers, and interrogatives occur the least with only 8 tokens $(0.2 \%$; prepositions) and 2 tokens ( $0 \%$; quantifiers). Likewise, in terms of type frequency, the table shows that it is most likely that nouns are to be borrowed rather than other word types with 663 occurences accounting for $80 \%$ of total borrowings. Verbs constitute $8 \%$, adjectives make up $7 \%$. Other types lag substantially behind, with $0 \%$ (prefixes), $1 \%$ (prepositions), and 1\% (adverbs).

Table 1. Percentage of English borrowings per word type in Hoa Hoc Tro

\begin{tabular}{|c|c|c|c|c|c|}
\hline Number & Word Type & Type frequency & $\begin{array}{c}\text { Percentage of type } \\
\text { frequency }\end{array}$ & $\begin{array}{c}\text { Token } \\
\text { frequency }\end{array}$ & $\begin{array}{c}\text { Percentage of } \\
\text { token frequency }\end{array}$ \\
\hline 1 & Noun & 663 & $80 \%$ & 4530 & $88.1 \%$ \\
\hline 2 & Verb & 67 & $8 \%$ & 214 & $4.2 \%$ \\
\hline 3 & Adjective & 59 & $7 \%$ & 182 & $3.5 \%$ \\
\hline 4 & $\begin{array}{c}\text { Exclamation / } \\
\text { interjection }\end{array}$ & 16 & $2 \%$ & 143 & $2.8 \%$ \\
\hline 5 & Pronoun & 5 & $1 \%$ & 29 & $0.6 \%$ \\
\hline 6 & Adverb & 11 & $1 \%$ & 17 & $0.3 \%$ \\
\hline 7 & Prefix & 3 & $0 \%$ & 13 & $0.3 \%$ \\
\hline 8 & Preposition & 4 & $1 \%$ & 8 & $0.2 \%$ \\
\hline 9 & $\begin{array}{c}\text { Quantifier, } \\
\text { interrogative }\end{array}$ & 2 & $0 \%$ & 2 & $0.0 \%$ \\
\hline & Total & $\mathbf{8 3 0}$ & $\mathbf{1 0 0 \%}$ & $\mathbf{5 1 3 8}$ & $\mathbf{1 0 0 \%}$ \\
\hline
\end{tabular}


It is apparent from Table 1 that nouns are borrowed more than other word types. The percentage of borrowed nouns, constituting $88.1 \%$ of the total borrowings, is similar to the percentage of nouns found in other studies (e.g. Field, 2002; Haugen, 1950). Various
The most frequent abbreviations are $C D$, $D N A, A I D S, C P U, M P 3, V I P$ and $V C D$. Many of the nouns are borrowed to denote new concepts (e.g., marketing, ballad, rock \& roll, and chatroom) and are distributed across various domains as shown in Table 2.

Table 2. Nouns in semantic fields

\begin{tabular}{|c|c|}
\hline Semantic fields & Nouns \\
\hline Addressing & Miss, Mister \\
\hline Economics & $\begin{array}{l}\text { dollar, marketing, business woman, money, customer, logo, bond, profit, USD, } \\
\text { bond exchange, broker, investor, stock, stock holder }\end{array}$ \\
\hline Expressions & baby, number one, VIP \\
\hline Fashion & jeans, shorts, silk, cotton, model, pull over, shop, shopping \\
\hline Foods \& Drinks & chewing gum, fast food, coffee, biscuit, bar, hot dogs, chocolate, cake, sandwich \\
\hline Lifestyle & picnic, seeing tour, hobby, weekend, party \\
\hline Medical & CT scanner, virus, AIDS, HIV, stress \\
\hline Miscellaneous & black board, worker, girl, toilet, topic, volume, forest \\
\hline Movies & scene, TV show, studio, ticket \\
\hline Music & $\begin{array}{l}\text { album, show, rock, pop, ballad, rock \& roll, hard rock, break dance, country, } \\
\text { jazz, top ten, hit, best seller, bill board, boyband, girlband, CD, poster }\end{array}$ \\
\hline $\begin{array}{l}\text { Science \& } \\
\text { Technology }\end{array}$ & $\begin{array}{l}\text { X-ray, robot, laser, gene, fax, IC (integrated circuit), mini lab, high tech, camera, } \\
\text { computer, internet, laptop, website, nickname, email, digital, mobile, phone }\end{array}$ \\
\hline Dimension & inch, feet \\
\hline Social Events & festival, Thanks Giving, Xmas, Halloween \\
\hline Sport & tennis, football, bowling, golf, fair play, hooligan, penalty, knock out \\
\hline Transportation & taxi, bus, skytrain \\
\hline
\end{tabular}

types of structural formations occur, including simple nouns, compounds, and abbreviations (including acronyms). Simple nouns take up $67.3 \%$, compound nouns account for $17.8 \%$ and abbreviations cover $14.9 \%$ of the total 4530 noun tokens. Compound nouns appear in noun + noun combinations such as best seller, bussiness woman, and money maker.
English verbs comprise $4.2 \%$ of the total 5138 borrowings. Due to the isolating characteristic of the Vietnamese language, verbs are all borrowed in their infinitive form (without 'to'), instead of past forms, third person singular, and so on. Verbs appear mainly in music, science and technology and miscellaneous domains and include cover, 
play back, photo, download, click, read, recognize, and chat. The most frequent verbs are cover (25 tokens), chat (20 tokens), and photo (20 tokens).

The adjective borrowings accounts for $3.5 \%$ of the total. The most widely borrowed adjectives include: big, mini, maximum, classic, new, romantic, modern, good, cool, hottest, cute, fantastic, smart, wonderful, handsome, and rich.

The proportion of adverbs, pronouns, prefixes, prepositions, and quantifiers is very low compared to that of other word classes. Some of the frequent borrowings of these word classes are very, really, hopefully, you, $I$, and super.

Apart from the major word classes (nouns, verbs, adjectives), interjections stand at the fourth highest position, used as independent discourse markers in the corpus. Some of the popular interjections are $O K$, hey, wow, yeah, and bye bye. For example:

(1) Hey, bọn tớ cũng đi Hawaii đây bọn tớ muốn cái lưng của bọn tớ có khái niệm về ánh nắng mặt trời. (iss. 299/1999)

Lit: Hey, we also go Hawaii here we want back of we have concept about beam sun.

Trans: Hey, we also go to Hawaii, we want our back have a sense of the sun light.

As mentioned earlier, of the 5138 English tokens in the corpus, a large number of nouns is recorded, with 4530 tokens (88.1\%), and the remaining $11.9 \%$ distributed among other classes such as verbs (4.2\%), adjectives (3.5\%), exclamations/interjections $(2.8 \%)$, pronouns $(0.6 \%)$, adverbs $(0.3 \%)$, prefixes $(0.3 \%)$, and prepositions $(0,2 \%)$. The scale of borrowability of this data is:

Nouns $>$ verbs $>$ adjectives $>$ exclamations/ interjections $>$ pronouns $>$ adverbs $>$ prefixes $>$ prepositions $>$ quantifiers

The quantification of borrowed word classes in this study supports the general trend of borrowing observed in other languages, where nouns are borrowed more frequently. The result of this study is consistent with the findings on borrowing in other languages, and supports the generalisation that certain word classes are more likely to be borrowed than others, regardless of the target language. The occurrence of large numbers of nouns, verbs, adverbs, and so on also reflects the high frequency of such word classes (especially nouns) in a language, word choice of users, and can relate to the syntactic systems of the languages involved.

The Vietnamese nouns and verbs have several important characteristics that affect the way English words are borrowed into Vietnamese, including transnumerality and verb-acting ability for nouns, and no infinitive form for verbs. Firstly, Vietnamese nouns 'do not themselves contain any notion of number and amount' because they have no obligatory marking of plural or singular (Ho, 2003: 5657). Furthermore, they have 'the property of transnumerality, [they are] invariant in form', and 'the nouns themselves remain the same regardless of whether they are singular or plural'. As a result, most of English nouns are borrowed in singular form. The following examples demonstrate this point:

(2) Áo thun dài lút tận đầu gối đi kèm với quần jean hoặc quần ống suôn thì mới là 'mốt' (iss. 133/96)

Lit: T-shirt long until knee go with trouser jean or trouser straight so new is 'fashion'

Trans: A long T-shirt with a pair of jeans or straight leg trousers is fashionable.

(3) Tơ đã phải bỏ tờ OK vì các poster của nó quá nhỏ [..] các fan ngày càng khó tính (iss. 259/98)

Lit: I already must put out paper $\mathrm{OK}$ because these poster of it too small [..] these fan day more strict.

Trans: I had to abandon $O K$ because its posters are too small [..] fans are getting harder to please. 
In the above examples, nouns are all in singular forms though most of them have indefinite numerals preceding them, such as nhüng, and các, which both refer to many in (3). In (2), jeans is borrowed in singular form which is vague in English since the word trousers, pants and jeans are always in plural form because they have two parts, but in Vietnamese the noun quần refers to the general concept of trousers, and is considered as one item. It can be combined with other nouns to define the type of trousers, such as quần bò 'jeans', and quần vải 'trousers'. These examples demonstrate the adaptation of English nouns into the transnumeral nature of Vietnamese grammar. Secondly, for an isolating language such as Vietnamese, nouns and verbs do not have to undergo morphosyntactic modification and verbs do not express tense (e.g., progress, perfect, and continuous) in themselves. Therefore, a noun can be placed in a verb's position and function as a verb because both nouns and verbs are inflected; there is no morphological impediment to a noun being converted into a verb or vice-versa. In other words, 'the Vietnamese language appears to permit a great deal of freedom in the selection of either nouns or verbs for syntactic combination' Ho (2003: 58). For example:

(4) hầu nhu tất cả các sự việc (tù đon giản đến phưc tạp) diễn ra ban ngày đều đurợc 'camera' y chang vào giấc ngủ đêm (iss. 167/1997)

Lit: ... almost all events (from simple to complicate) happen day time both are camera exactly to sleep night

Trans: Almost all events (from simple to complicate) that happen in the day time are recorded and shown exactly in night time sleep.

(5) Khâu đầu tiên là phải marketing đã (iss. 248/1998)

Lit: Part first is must marketing already

Trans: Marketing is the first part
In (4) and (5) camera and marketing appear in noun form but are placed in the position of the verb and act as Vietnamese verbs. No cases of verbs acting as nouns are found in the corpus.

Turning to English verbs found in the corpus, the data shows that English verbs are borrowed in infinitive (without to) form, and there is no morphosyntactic modification recorded. Borrowed verbs are inserted directly and they do not need to undergo a verbalisation process before they become available in the recipient language (Wohlgemuth, 2009: 265). The findings of this study, therefore, do not match with the constraint proposed by Moravcsik (cited from Curnow, 2001: 419) that verbs are usually borrowed as non-verbs. Moravcsik claims that after being imported as non-verbs, the word would then undergo a process of verbalisation before being used as verbs in the borrowing language. Moravcsik states that 'a lexical item whose meaning is verbal can never be included in the set of borrowed properties'. This implies that morphosyntactic modification must be applied when borrowing a verb, that is, a borrowed verb has to be modified to fit in the existing verbal classes of the recipient language. However, the generalisation is not applicable to an isolating language such as Vietnamese where the verb can be directly inserted without any morphosyntactic modification, as in the case of adapted spelling: phô tô 'photo', đi dai 'design', pho ghét 'forget', or with the original spelling, as for check and stop. In the following example, the English verbs design (6) and cover (7) are borrowed with their original forms with no modification:

(6) '..các bạn gái ở trên mạng khắp thế giới sẽ được tặng miễn phí một món quà rất đặc biệt do hắn design..'. (iss. 299/1999)

Lit: those friend girl on net around world will be give free one present very special by he design 
Trans: .... girlfriends on the internet around the world will be given a free and very special gift that he designs...

(7) Tuy nhiên nếu một nghệ sĩ hoặc một ban nhạc mà cú đi cover mãi thì ta nên goi chuyên gia hát lại thì hơn. (291/1999)

Lit: However, if one artist or one band music that go cover that we should call expert sing repeat better

Trans: However, if an artist or a band always covers songs of others, it is better to call them expert in singing others' songs.

Again, these examples demonstrate that English verbs can be borrowed as verbs and they do not have to undergo a process of verbalisation in Vietnamese language.

Despite the fact that this isolating characteristic of the Vietnamese language allows all word classes to be borrowed without any morphosyntactic modification, the number of nouns is still the highest among the word types borrowed. Hence, grammatical factors are not the reason for the high rate of noun borrowings into the Vietnamese language. Instead, the explanation probably lies in the fact that concepts and objects themselves, which are usually denoted by nouns, are more frequently and easily borrowed from other cultures to fill gaps or to replace existing concepts. Verbs, on the other hand, are not as easily borrowed as nouns because they refer to actions, which are less likely to be new ideas to a culture, so that suitable words already exist. For example, the verb cover refers to a very culture-specific action, and it is borrowed. Likewise, camera (as a verb) refers to a technologically new action, and so on.

Due to the isolating characteristic of Vietnamese language, other word types such as adverbs and adjectives do not have to undergo morphosyntactic modification when being imported into the language. However, the borrowing rates of these word types in the corpus are low compared with nouns and verbs.

\section{Conclusion}

It is shown that different syntactic word classes are borrowed at different rates. For instance, borrowing of nouns is the most common whereas borrowing quantifiers is the least common, and no article is found in the corpus. A possible explanation is that nouns, verbs, adjectives, and other word classes exist in both languages with structural equivalence, while articles are not used in Vietnamese. Therefore, borrowing of other word classes (nouns, verbs, and adjectives) rather than articles occurs. Moreover, grammatical items are less likely to be borrowed than content words. In addition, new concepts are normally represented by nouns, which make the number of borrowed nouns increase accordingly. The results also show that English words have adapted into the features of Vietnamese grammar during the borrowing process. Firstly, due to the transnumeral feature of Vietnamese grammar, English nouns are borrowed mostly in singular form and they can act as verbs in some cases, as long as the intended meaning is fulfilled. Secondly, Vietnamese is an isolating language, so verbs are borrowed in their original forms without any morphosyntactic modification. Because most new concepts are denoted by nouns and in Vietnamese nouns can act as verbs via zeroderivation, the number of borrowed nouns accounts for the high percentage of $88.1 \%$. This result supports the view that nouns are the most frequently borrowed forms. However, it also challenges previous generalisations about the borrowing of verbs.

\section{References}

\section{English}

Aitchison, J. (2000). Language change: progress or decay? Cambridge: Cambridge University Press.

Appel, R., \& Muysken, P. (1987). Language contact and bilingualism. London; Melbourne: Adward Arnold. 
Bussmann, H. (1996). Routledge dictionary of language and linguistics. London: Routledge.

Clyne, M. (2003). Dynamics of language contact: English and immigrant languages. United Kingdom: Cambridge University Press.

Curnow, T. J. (2001). What language features can be 'borrowed'. In A. Y. Aikhenvald \& R. M. W. Dixon (Eds.), Areal diffusion and genetic inheritance: problems in comparative linguistics (pp. 412-436). The United States: Oxford University.

Field, F. W. (2002). Linguistic borrowing in bilingual contexts (Vol. 62). Amsterdam: John Benjamins Publishing Company.

Haspelmath, M., \& Tadmor, U. (2009). Loanwords in the world's languages: a comparative handbook. Berlin, Germany: Walter de Gruyter.

Haugen, E. (1950). The analysis of linguistic borrowing. Language, 26(2), 210-231.

Haugen, E. (1992). Borrowing: An Overview. In W. Bright (Ed.), International Encyclopedia of Linguistics (pp. 197-200). Oxford: Oxford University Press.

Haugen, E. (1956). Bilingualism in the Americas: a bibliography and research guide. Alabama: American Dialect Society; Obtainable from University of Alabama Press.

Ho, D. T. (2003). Vietnamese-English bilingualism: Patterns of code-switching. London: Routledge Curzon.

Johanson, L. (2002). Structural factors in Turkic language contacts. Richmond, England: RoutledgeCurzon.
Onysko, A. (2007). Anglicisms in German: Borrowing, lexical productivity, and written codeswitching (Vol. 23). Berlin; New York: De Gruyter.

Robins, R. H. (1989). General Linguistics An Introductory Survey. London and New York: Longman.

Thomason, S. G. (2006). Language Change and Language Contact. Encyclopedia of Language \& Linguistics, 2, 339-346.

Thomason, S. G. (2001). Language contact. Edinburgh: Edinburgh University Press.

Thomason, S. G. (2001). Contact-induced language change and pidgin/creole genesis. In N. Smith \& T. Veenstra (Eds.), Creolization and Contact (pp. 249-262). The Netherlands: John Benjamins Publishing Co.

Van Hout, R., \& Muysken, P. (1994). Modeling lexical borrowability. Language variation and change, 6(01), 39-62.

Whitney, W. D. (1881). On mixture in language. Transactions of the American Philological Association (1869-1896), 12, 5-26.

Wohlgemuth, J. (2009). A typology of verbal borrowings (Vol. 211). Berlin: De Gruyter Mouton.

\section{Vietnamese}

Nguyễn Văn Khang (2007). Tù ngoại lai trong tiếng Việt. Hà Nội: Nhà Xuất Bản Giáo Dục.

Dương Toàn (2011, 10/01/2013). Báo Hoa Học Trò kỷ niệm 20 năm ngày phát hành số báo đầu tiên. Retrieved from http://www.tienphong.vn/xahoi/554203/\%20-tpov.html

\title{
TỬ MƯợN TIẾNG ANH VÀ MỨC ĐỘ VAY MƯợN TRONG TẠP CHÍ TIẾNG VIẸT
}

\author{
Nguyễn Thúy Nga \\ Truòng Đại học Su phạm Hà Nội, 136 Xuân Thủy, Cầu Giấy, Hà Nội, Việt Nam
}

Tóm tắt: Trong bối cảnh toàn cầu hóa, việc tiếp xúc giữa các ngôn ngữ là điều không tránh khỏi. Vay mượn từ vựng là một sản phẩm của quá trình tiếp xúc này khi có sự trao đổi, tương tác giữa hai hoặc nhiều hơn hai ngôn ngữ. Bài viết nghiên cứu tỉ lệ vay mượn từ loại tiếng Anh trong tạp chí Hoa Học Trò dành cho lứa tuổi thanh thiếu niên. Các kết quả cho thấy quy tắc cú pháp của tiếng Việt có ảnh hưởng lớn trong việc vay mượn từ và chuyển loại từ của các từ mượn tiếng Anh.

Tù khóa: tiếp xúc ngôn ngữ, từ mượn, tiếng Anh, mức độ vay mượn 